\title{
ЭЛЕКТРОМАГНИТНАЯ СУШКА ВЛАЖНЫХ МАТЕРИАЛОВ С МАЛОЙ ГЛУБИНОЙ ПРОНИКНОВЕНИЯ СВЧ-ИЗЛУЧЕНИЯ В УСЛОВИЯХ ТЕПЛОСБРОСА РАДИАЦИЕЙ И КОНВЕКЦИЕЙ. II. СТАДИЯ ПОСТОЯННОЙ СКОРОСТИ СУШКИ
}

Саломатов Владимир Васильевич ${ }^{1,2}$, salomatov.vv@mail.ru

Карелин Вадим Александрович 1,2, vad2hen@mail.ru

\author{
Саломатов Василий Владимирович², \\ vvsalomatov@mail.ru \\ 1 Новосибирский государственный университет, \\ Россия, 630090, г. Новосибирск, ул. Пирогова, 1. \\ 2 Институт теплофизики им. С.С. Кутателадзе СО РАН, \\ Россия, 630090, г. Новосибирск, пр. Академика Лаврентьева, 1.
}

\begin{abstract}
Актуальность исследования продиктована необходимостью разработки математических моделей СВЧ-нагрева и МВ-сушки влажных материалов для получения технологически оптимальных и экономически выгодных режимов. Настоящая публикация является продолжением статьи тех же авторов в «Известия Томского политехнического университета. Инжиниринг георесурсов", в которой с помощью математического моделирования подробно была изучена первая стадия сушки - стадия прогрева, когда теплообмен между поверхностью влажного тела и окружающей средой осуществляется за счет радиации и конвекции, а СВЧ-энергия поглощается поверхностным слоем из-за малой её глубины проникновения. Построены асимптотические решения этой нелинейной задачи для малых и больших значений безразмерного времени, востребованные инженерной практикой, как для параметрического анализа, так и для проведения оперативных расчетов. Подход, связанный с рассмотрением второй стадии - стадии постоянной скорости сушки - основан на более детальном изучении теплопереноса, а расчет скорости сушки ведется с использованием аппроксимационной зависимости А.В. Лыкова. Также предложено условие сшивки тепловых режимов I и II стадий процесса сушки.

Цель: постановка задачи второго этапа СВЧ-сушки влажного материала - этапа постоянной скорости сушки - и реализация теоретического решения по определению распределения температурного поля по толщине слоя и величины скорости сушки. Объектом исследования является плоский слой влажного материала - уголь, песок, древесина и др. капиллярно-пористые массивы, на которые воздействует СВЧ-излучение. Такие материалы обладают высокой диэлектрической проницаемостью и как следствие весьма эффективно поглощают СвЧ-излучение, которое почти на 100 \% преобразуется в тепловую энергию.

Методы исследования связаны с математическим моделированием, в основе которого лежат уравнения электродинамики Максвелла и тепловлагопереноса А.В. Лыкова. В данной статье задача Максвелла решена независимо от задачи тепломассопереноса, поэтому плотность потока СВЧ-излучения считается известной. Также одной из особенностей данной задачи является рассмотрение материалов с малой глубиной поглощения, в силу чего в системе уравнений для нагрева источниковый член находится в граничном условии.

В результате исследования с привлечением условий стационарного температурного поля и постоянства во времени плотности потока влагосодержания сформулирована и решена задача распределения температурного поля по толщине влажной пластины, которое строго следует закону квадратной параболы. Скорость сушки I/ стадии и критическое влагосодержание в конце I/ стадии определены из корреляционных зависимостей А.В. Лыкова. Дана сшивка решений для I и II стадии. Выполнен анализ построенных решений.
\end{abstract}

\section{Ключевые слова:}

СВЧ-энергия, электромагнитная сушка, капиллярно-пористый массив, теплоизлучение, конвекция, уравнения тепловлагопереноса А.В. Лыкова, скорость сушки.

\section{Введение}

Обзор литературных источников [1-9] по применению электромагнитных волн для сушки влажных материалов показывает, что данная сфера исследований неуклонно расширяется. Связано последнее главным образом с особенностями поведения такого важного электрофизического параметра, как диэлектрическая проницаемость воды. Она имеет максимум в области СВЧ-диапазона электромагнитных волн. В результате электромагнитной сушки энергия на испарение воды из влажного материала доставляется за счет поглощения
СВЧ-излучения, так как подсушиваемая среда изза наличия влаги всегда обладает диэлектрическими свойствами.

Для СВЧ-сушки выделены следующие частоты: 433, 915 и 2450 МГц. Как правило, энергия микроволн подводится к высушиваемому объекту с помощью волноводов. В качестве генераторов СВЧ-излучения наибольшее распространение получили магнетроны.

Известны неоспоримые преимущества сушки микроволнами [10-15]: равномерный объемный нагрев, тепловая безынерционность, избиратель- 
ный саморегулирующий нагрев, так как сушка подсушенных мест самопроизвольно прекращается. В этой связи с уменьшением влажности пропорционально снижается тангенс диэлектрических потерь и расход СВЧ-энергии существенно экономится

Следует принять во внимание, что вводимая СВЧ-мощность возрастает с увеличением частоты микроволнового излучения, но одновременно с этим ростом уменьшается глубина проникновения электромагнитного излучения, и оно становится практически поверхностным источником. Диэлектрическая сушка незаменима в тех случаях, когда требуется высокая скорость сушки. В этих режимaх СВЧ-сушка является рентабельной за счет снижения капзатрат в связи с сокращением длительности самой сушки [16-18].

Основой теории электромагнитной сушки является поиск закономерностей переноса тепла и влаги во влажных материалах в процессе облучения электромагнитными волнами при наличии фазового превращения воды в пар.

Как показывает эксперимент, термическая обработка влажного материала включает в себя три стадии: начальная - прогрев, средняя - сушка с постоянной скоростью, заключительная - падающая скорость сушки. В работе полагается, что физические свойства материала постоянны.

Процесс испарения идет исключительно с поверхности влажного тела. Температура поверхности в этом периоде остается неизменной.

Для сушки важное значение имеет знание температуры материала. В периоде постоянной скорости сушки температура материала равна температуре мокрого термометра, если подвод тепла, необходимого для испарения влаги и нагревания материала, осуществляется нагретым воздухом. При наличии дополнительного подвода тепла теплопроводностью и теплоизлучением температура материала на его поверхности будет выше температуры мокрого термометра.

На первой стадии - стадии прогрева - жидкость практически не удаляется. Здесь вся приходящая энергия тратится на нагрев влажного материала. На второй стадии подводимая энергия расходуется главным образом на испарение влаги и повышения температуры тела нет. Эта стадия постоянной скорости сушки. Главная её особенность состоит в том, что тепловой режим становится стационарным, все характеристики слоя не меняются со временем и не зависят от начального состояния. Сама скорость сушки равна постоянному значению и не меняется на данной стадии. После чего наступает третья стадия - стадия падающей скорости сушки, когда оставшаяся влага окончательно испаряется, а температура материала растет вплоть до равновесия с окружающей средой. Математически параметры влажного тела для второй стадии приобретают вид [19, 20]:

$$
\frac{\partial T}{\partial t}=0, \quad \frac{\partial q_{I I}}{\partial t}=0, \quad \frac{\partial j_{I I}}{\partial t}=0, \quad \frac{\partial u}{\partial t}=\text { const. }
$$

Здесь первое условие говорит о стационарности процесса сушки; второе и третье условия свидетельствуют о том, что поток тепла и поток влаги принимают постоянные значения и во времени не претерпевают изменения; и, наконец, четвертое условие утверждает, что влагосодержание в слое убывает по времени с одной и той же скоростью.

\section{Стадия постоянной скорости сушки}

Данная стадия характеризуется следующими условиями (1).

$$
\frac{\partial T}{\partial t}=0, \quad \frac{\partial u}{\partial t}=-\frac{j_{n}}{\rho_{0} l},
$$

где $j_{n}$ - плотность потока влаги у поверхности тела (или интенсивность сушки); $l$ - полутолщина слоя.

Уравнение стационарной теплопроводности с внутренним источником имеет вид:

$$
a \frac{\partial^{2} T}{\partial x^{2}}-\frac{\varepsilon r_{p} j_{n}}{c \rho_{0} l}=0
$$

Здесь $\varepsilon=\frac{d_{i} u}{d u}-$ коэффициент фазового превращения жидкости в пар, равный отношению изменения влагосодержания за счет испарения к общему изменению влагосодержания; $r_{p}$ - удельная теплота фазового перехода, Дж/кг.

Интегрируя (2) получим:

$$
\frac{\partial T}{\partial x}=\frac{\varepsilon r_{p} j_{n}}{\lambda l} x+c_{1} \text {. }
$$

При этом граничным условием для (3) является выражение (4).

$$
\begin{aligned}
& \left.\frac{d T}{d x}\right|_{x=0}=0 ; \quad c_{1}=0 ; \\
& T(x)=\frac{\varepsilon r_{p} j_{n}}{\lambda l} \frac{x^{2}}{2}+c_{2} .
\end{aligned}
$$

Для выражения (3) должно выполняться также второе краевое условие (6):

$$
\begin{gathered}
\left.\frac{d T}{d x}\right|_{x=1}=\frac{q_{w}}{\lambda}-\frac{\alpha}{\lambda}\left(T(l)-T_{c}\right)- \\
-\frac{\varepsilon_{2} \sigma_{0}}{\lambda}\left(T^{4}(l)-T_{c}^{4}\right)-\frac{r_{p}}{\lambda}(1-\varepsilon) j_{n}(l, t) ; \\
\frac{q_{w}}{\lambda}-\frac{\alpha}{\lambda}\left(T(l)-T_{c}\right)-\frac{\varepsilon_{2} \sigma_{0}}{\lambda}\left(T^{4}(l)-T_{c}^{4}\right)-\frac{r_{p} j_{n}}{\lambda}=0 .
\end{gathered}
$$

Здесь (7) - алгебраическое уравнение 4 степени, которое разрешено в радикалах. Действительный положительный корень равен

где

$$
\begin{array}{r}
T(l)=\frac{1}{2}\left(\sqrt{-A+B}+\sqrt{A-B \pm \frac{2 a}{b \sqrt{-A+B}}}\right), \\
A=\frac{4\left(\frac{2}{3}\right)^{\frac{1}{3}} c}{\left(9 a^{2} b+\sqrt{3} \sqrt{27 a^{4} b^{2}+256 b^{3} c^{3}}\right)^{\frac{1}{3}}} ;
\end{array}
$$




$$
\begin{gathered}
B=\frac{\left(9 a^{2} b+\sqrt{3} \sqrt{27 a^{4} b^{2}+256 b^{3} c^{3}}\right)^{\frac{1}{3}}}{2^{\frac{1}{3}} 3^{\frac{2}{3}} b} \\
a=-\frac{\alpha}{\lambda} ; \\
b=-\frac{\varepsilon_{2} \sigma_{0}}{\lambda} ; \\
c=-\frac{q_{w}}{\lambda}-\frac{\alpha}{\lambda} T_{c}-\frac{\varepsilon_{2} \sigma_{0}}{\lambda} T_{c}^{4}+\frac{r}{\lambda} j_{n} .
\end{gathered}
$$

Тогда

$$
\begin{aligned}
& T(l)=\frac{\varepsilon r_{p} j_{n}}{\lambda} \frac{l}{2}+C_{2} ; \\
& C_{2}=T(l)-\frac{\varepsilon r_{p} j_{n}}{\lambda} \frac{l}{2} .
\end{aligned}
$$

Подставим (8) в (5) и получим окончательное решение (9):

$$
T(x)=T(l)-\frac{\varepsilon r_{p} j_{n} l}{2 \lambda}\left(1-\frac{x^{2}}{l^{2}}\right) .
$$

Типичный вид распределения выглядит следующим образом - рисунок.

Для расчетов взяты следующие параметры:

$$
\begin{gathered}
\alpha=10, \frac{\mathrm{BT}}{\mathrm{M}^{2}} ; \varepsilon_{2}=0.9 ; r_{p}=2,3 \cdot 10^{6}, \frac{\text { Дж }}{\mathrm{\kappa} \Gamma} ; \\
q_{w}=12 \cdot 10^{3}, \frac{\mathrm{BT}}{\mathrm{M}^{2}} ; T_{c}=300, K ; l=0,1, \mathrm{M} ; \\
\lambda=0,2, \frac{\mathrm{BT}}{\mathrm{M} \cdot \mathrm{K}} ; j_{n}=10^{-4}, \frac{\mathrm{\kappa} \Gamma}{\mathrm{M}^{2} \mathrm{c}} ; \varepsilon=0,5 .
\end{gathered}
$$

Исходя из уравнения (2), распределение температуры внутри влажного тела подчиняется закону параболы второй степени (9), а само решение в критериальном виде подчиняется следующему выражению

$$
\frac{T(l)-T_{c}}{T_{c}-T_{0}}=\frac{1}{2} \mathrm{Ki}_{m_{I I}} \varepsilon \mathrm{KoLu} .
$$

Теплообменный и массообменный критерии Кирпичева зависит друг от друга на этой стадии следующим образом:

$$
\mathrm{Ki}_{q_{I I}}=\mathrm{Ki}_{m_{\|}} \text {LuKo, }
$$

где

$$
\mathrm{Lu}=\frac{a_{m}}{a}, \mathrm{Ko}=\frac{r \bar{u}_{0}}{c T_{c}}, \mathrm{Ki}_{q_{I I}}=\frac{q_{n} l}{\lambda T_{c}}, \mathrm{Ki}_{m_{I I}}=\frac{j_{n} l}{a_{m} \rho_{0} q_{0}} .
$$

Если обозначить скорость сушки через $\mathrm{N}(\% / \mathrm{c})$ во второй стадии $N=\left(\frac{d w}{d t}\right)_{I I}$, то $\mathrm{Ki}_{m_{H}}$ будет связан с этой характеристикой следующим образом:

$$
\mathrm{Ki}_{m_{I}}=\frac{l^{2} N}{a_{m} W_{0}} .
$$

Конец стадии постоянной скорости сушки определяется критическим влагосодержанием (средним по объему), которое находится из выражения [19]:

$$
\frac{W_{\mathrm{xp}_{I I}}-W_{p}}{W_{0}-W_{p}}=\frac{1}{3} \mathrm{Ki}_{m}\left(1+\varepsilon \frac{r \delta a_{m}}{c a}\right) \text {. }
$$

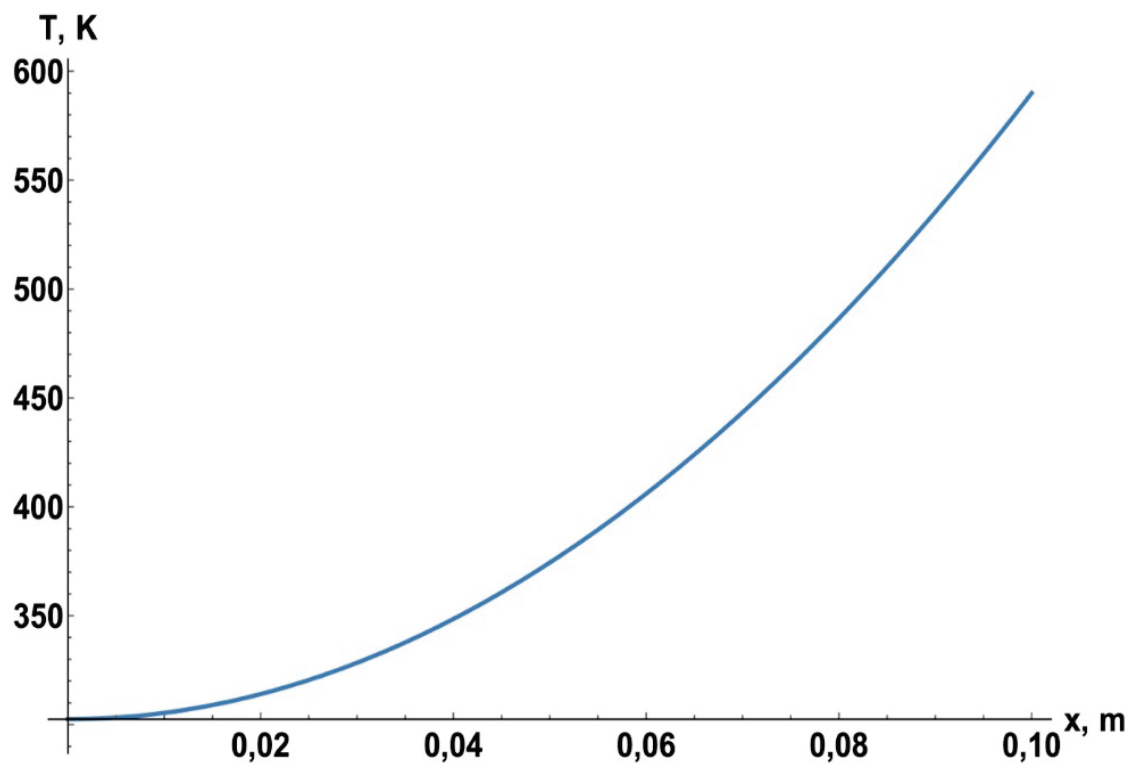

Рисунок. Температура слоя в зависилости от глубины слоя. $x=0$ - задняя поверхность слоя, $x=l=0,1 \mathrm{~m}-$ поверхность, на которую падает СВЧ-волна

Figure. Layer temperature depending on the depth of the layer. $x=0$ is the back surface of the layer, $x=l=0,1 \mathrm{~m}$ is the surface on which the microwave wave falls 


\section{Список условных обозначений величин}

$q_{I I}$ - поток тепла, $\frac{\mathrm{BT}}{\mathrm{M}^{2}}$;

$q_{w}$ - поток тепла на поверхности, $\frac{\mathrm{BT}}{\mathrm{M}^{2}}$;

$T$ - температура по глубине слоя,К;

u-влагосодержание;

$\bar{u}_{0}$ - среднее влагосодержание;

$t$-время, с;

$x$ - декартова координата, м;

$l$ - полутолщина плоского слоя, м;

$c_{2}, \rho_{0}, \lambda, r_{p}, \varepsilon, a_{m}, a_{M}^{T}$ - теплофизические характеристики материала:

теплоемкость, плотность, теплопроводность, удельная теплота парообразования,

коэффициенты испарения, диффузии влаги и термодиффузии влаги соответственно;

$a$-коэффициент температуропроводности;

$\alpha$-коэффициент конвективного теплообмена, $\frac{\mathrm{BT}}{\mathrm{M}^{2} \mathrm{~K}}$;

$\varepsilon_{2}-$ степень черноты поверхности;

$\sigma_{0}$ - константа теплового излучения абсолютно черной поверхности, $\frac{\mathrm{BT}}{\mathrm{M}^{2} \mathrm{~K}^{4}}$;

$T_{c}$ - температура окружающего пространства, К;

$j_{I I}-$ плотность потока влаги, $\frac{\text { кг }}{\mathrm{M}^{2} \mathrm{c}}$;

$j_{n}$ - плотность потока влаги на поверхности, $\frac{\text { кг }}{\mathrm{M}^{2} \mathrm{c}}$;

$K i_{m}=\frac{j w l}{a_{m} \rho_{0} \overline{u_{0}}}-$ массобменный критерий Кирпичева;

$K i_{q}=\frac{q_{w} l}{\lambda T_{c}}-$ теплообменный критерий Кирпичева.

\section{Заключение}

Рассмотрен процесс электромагнитной сушки влажного плоского слоя на II стадии - стадии постоянной скорости сушки. В условиях стационарного температурного поля и постоянства во времени плотности потока влагосодержания сформулирована и решена задача распределения температурного поля по толщине влажной пластины. Данное решение имеет параболическую структуру. Температура на поверхности пластины найдена из балансового соотношения нагрева и испарения в ре- жиме малой глубины проникновения микроволнового излучения как действительный положительный корень алгебраического уравнения четвертой степени. Скорость сушки II стадии и критическое влагосодержание в конце II стадии определены из корреляционных зависимостей А.В. Лыкова. Дается сшивка решений для I и II стадии.

Исследование и постановка задачи для стадии постолнной скорости сушки выполнены в рамках государственного задания ИТ СО РАН, поиск приближенных аналитических решений выполнен за счет гранта РФФИ (№ 17-08-00752). 


\section{СПИСОК ЛИТЕРАТУРЫ}

1. Коновалов Н.П. Технология деструкции бурых углей методом нагрева энергией сверхвысоких частот. - Иркутск: Изд-во ИрГТУ, 2000. - 92 c.

2. Three-dimensional simulation of microwave heating coal sample with varying parameters / Yi-du Hong, Bai-quan Lin, He Li, Huaming Dai, Chuan-jie Zhu, HaoYao // Applied Thermal Engineering. - 2016. - V. 93. - P. 1145-1154.

3. Sensitivity analysis on the microwave heating of coal: A coupled electromagnetic and heat transfer model / Baiquan Lin, $\mathrm{He} \mathrm{Li}$, Zhongwei Chen, Chunshan Zheng, Yidu Hong, ZhengWang // Applied Thermal Engineering. - 2017. - V. 126. - P. 949-962.

4. Meda V., Orsat V., Raghavan V. Microwave heating and the dielectric properties of foods // The Microwave Processing of Foods. Cambridge: Woodhead Publishing, 2017. - P. 23-43. URL: https://www.elsevier.com/books/the-microwave-processing-offoods/regier/978-0-08-100528-6 (дата обращения 28.09.2019).

5. Microwave drying performance of single-particle coal slime and energy consumption analyses / Zhanlong Song, Chuanming Jing, Liansheng Yao, Xiqiang Zhao, Wenlong Wang, Yanpeng Mao, Chunyuan Ma // Fuel Processing Technology. - 2016. - V. 143. P. 69-78.

6. Faisal Mushtaq, Ramli Mat, Farid Nasir Ani. Fuel production from microwave assisted pyrolysis of coal with carbon surfaces // Energy Conversion and Management. - 2016. - V. 110. P. $142-153$.

7. Drying behavior of lignite under microwave heating / Zhanlong Song, Liansheng Yao, Chuanming Jing, Xiqiang Zhao, Wenlong Wang \& Chunyuan Ma // Drying Technology. -2017. - V. 35. P. 433-443.

8. Radha Raman Mishra, Apurbba Kumar Sharma. Microwave-material interaction phenomena: heating mechanisms, challenges and opportunities in material processing // Composites Part A: Applied Science and Manufacturing. - 2016. - V. 81. - P. 78-97.

9. Temperature rise characteristics of Zhun Dong coal during microwave pyrolysis / Huan-Peng Liu, Tai-Ping Chen, Yang Li, Zhen-Yu Song, Shao-Wei Wang, Shao-Hua Wu / / Fuel Processing Technology. - 2016. - V. 148. - P. 317-323.

10. Хайдурова А.А., Федчишин В.В., Коновалов Н.П. Микроволновая сушка бурых углей и повышение их технологических характеристик // Изв. ВУЗов. Проблемы энергетики. - Казань: Изд-во КГЭУ, 2010. - С. 31-35.

11. Methods and systems for processing solid fuel. US20090272028A1 United States: pat. USA 2007/0295.590.

12. Effect of microwave irradiation on the preparation of iron oxide/arenaceous clay sorbent for hot coal gas desulfurization / Yu Feng, Tianqi Hu, Mengmeng Wu, Ju Shangguan, Huilin Fan, Jie Mi // Fuel Processing Technology. - 2016. - V. 148. P. $35-42$.

13. Experimental study on the petrophysical variation of different rank coals with microwave treatment / He Li, Baiquan Lin, Wei Yang, Chunshan Zheng, Yidu Hong, Yabin Gao, Tong Liu, Shiliang Wu // International Journal of Coal Geology. - 2016. V. $154-155 .-$ P. $82-91$.

14. Activated carbon obtained from sapelli wood sawdust by microwave heating for 0-cresol adsorption. / P.S. Thue, G.S. dos Reis, E.C. Lima, J.M. Sieliechi, G.L. Dotto, A.G.N. Wamba, S.L.P. Dias, F.A. Pavan // Research on Chemical Intermediates. - February 2017 . - V. 43. - Iss. 2. - P. 1063-1087.

15. Effect of microwave irradiation on petrophysical characterization of coals / Hong Yi-du, Lin Bai-quan, Zhu Chuan-jie, Li He // Applied Thermal Engineering. - 5 June 2016. - V. 102. P. 1109-1125.

16. Jing Sun, Wenlong Wang, Qinyan Yue. Review on microwavematter interaction fundamentals and efficient microwave-associated heating strategies // Materials. - 2016. - P. 231. DOI: $10.3390 / \mathrm{ma} 9040231$.

17. Reddy B.R., Vinu R. Microwave assisted pyrolysis of Indian and Indonesian coals and product characterization // Fuel Processing Technology. - 2016. - V. 154. - P. 96-103.

18. Microwave absorption characteristics of anthracite during pyrolysis / Zhiwei Peng, Xiaolong Lin, Xuejiao Wu, Jiann-Yang Hwang, Byoung-Gon Kim, Yuanbo Zhang, Guanghui Li, Tao Jiang // Fuel Processing Technology. - 2016. - V. 150. - P. 58-63.

19. Лыков А.В. Теория теплопроводности. - М.: Изд-во «Высшая школа» 1967. - $600 \mathrm{c}$.

20. Лыков А.В. Теория сушки. - М.: Изд-во «Энергия», 1968. $471 \mathrm{c.}$

Поступила 04.10.2019 2.

\section{Информация об авторах}

Саломатов В.В., доктор технических наук, профессор кафедры физики неравновесных процессов Новосибирского государственного университета; главный научный сотрудник института теплофизики им. С.С. Кутателадзе СО РАН.

Карелин B.A., аспирант кафедры физики неравновесных процессов Новосибирского государственного университета; инженер-исследователь института теплофизики им. С.С. Кутателадзе СО РАН.

Саломатов B.B., кандидат физико-математических наук, ведущий программист института теплофизики им. С.С. Кутателадзе СО РАН. 


\title{
ELECTROMAGNETIC DRYING OF WET MATERIALS WITH A SMALL DEPTH OF PENETRATION OF MICROWAVE RADIATION IN THE CONDITIONS OF HEAT REMOVAL BY RADIATION AND CONVECTION. II. STAGE OF CONSTANT DRYING SPEED
}

\author{
Vladimir V. Salomatov ${ }^{12}$, \\ salomatov.vv@mail.ru \\ Vadim A. Karelin ${ }^{1,2}$, \\ vad2hen@mail.ru \\ Vasiliy V. Salomatov, \\ vvsalomatov@mail.ru \\ 1 Novosibirsk State University, \\ 1, Pirogov street, Novosibirsk, 630090, Russia \\ ${ }^{2}$ Institute of Thermophysics. S.S. Kutateladze SB RAS, \\ 1, Academician Lavrentiev avenue, Novosibirsk, 630090, Russia.
}

The relevance of the research is dictated by the need to develop mathematical models of microwave heating and MW-drying of wet materials to obtain technologically optimal and cost-effective modes. This publication is a continuation of the article by the same authors in "Bulletin of the Tomsk Polytechnic University. Geo Assets Engineering», in which the authors using mathematical modeling, studied in detail the process at the first stage of drying -the heating stage, when heat exchange between the surface of a moist body and the environment is due to radiation and convection - energy is absorbed by the surface layer due to its small depth of penetration. The authors constructed the asymptotic solutions of this nonlinear problem for small and large values of dimensionless time demanded by engineering practice, both for parametric analysis, and for carrying out operational calculations. The approach associated with the consideration of the second stage, the stage of constant drying rate, is based on a more detailed study of heat transfer, and the calculation of the rate of drying is carried out using the approximation dependence of A. V. Lykov. The paper proposes a condition for cross-linking of thermal modes of I and II stages of drying.

The aim of the research is the state of the problem of the second stage of microwave drying of wet material - a stage of constant drying rate - and implementation of a theoretical solution to determine the distribution of the temperature field across the layer thickness and the magnitude of the drying rate.

The object of the research is a flat layer of wet material - coal, sand, wood, and other capillary-porous arrays, which are affected by microwave radiation. Such materials have a high dielectric constant and, as a result, very effectively absorb microwave radiation, which is almost $100 \%$ converted to thermal energy.

The research methods are associated with mathematical modeling, which are based on Maxwell's electrodynamics equations and A.V. Lykov heat and moisture transfer. In this article, the Maxwell problem is solved independently of the problem of heat and mass transfer; therefore, the flux density absorbed by microwave radiation is known. Also, one of the features of this problem is the consideration of materials with a small absorption depth, that is why the source term in the system of equations for heating is in the boundary condition.

As a result of the research, the authors involving the stationary temperature field conditions and the constancy of the moisture content flux density over time stated and solved the problem of temperature field distribution across the thickness of the wet plate, which strictly follows the square parabolic law. The drying speed of the II stage and the critical moisture content at the end of the II stage were determined from A.V. Lykov correlation dependencies. The paper introduces the stitching solutions for the I and II stages and the analysis of the constructed solutions.

\section{Key words:}

Microwave energy, electromagnetic drying, capillary-porous massif, heat radiation, convection

A.V. Lykov heat and moisture transfer equations, drying speed.

The statement of the problem and solution for the stage of constant drying rate were performed within the framework of the state task IT SB RAS, the search for approximate analytical solutions was done with the support of the Russian Foundation for Basic Research, grant no. 17-08-00752.

\section{REFERENCES}

1. Konovalov N. P. Tekhnologiya destruktsii burykh ugley metodom nagreva energiey sverkhvysokikh chastot [Technology of brown coal destruction by the method of heating by energy of ultrahigh frequencies]. Irkutsk, IrSTU Publ. house, 2000. 92 p.

2. Yi-du Hong, Bai-quan Lin, He Li, Hua-ming Dai, Chuan-jie Zhu, HaoYao. Three-dimensional simulation of microwave heating coal sample with varying parameters. Applied Thermal Engineering, 2016, vol. 93, pp. 1145-1154.
3. Baiquan Lin, He Li, Zhongwei Chen, Chunshan Zheng, Yidu Hong, Zheng Wang. Sensitivity analysis on the microwave heating of coal: A coupled electromagnetic and heat transfer model. Applied Thermal Engineering, 2017, vol. 126, pp. 949-962.

4. Meda V., Orsat V., Raghavan V. Microwave heating and the dielectric properties of foods. The Microwave Processing of Foods. Cambridge, Woodhead Publishing, 2017. pp. 23-43. Available at: https://www.elsevier.com/books/the-microwave-processing-offoods/regier/978-0-08-100528-6 (accessed 28 September 2019). 
5. Zhanlong Song, Chuanming Jing, Liansheng Yao, Xiqiang Zhao, Wenlong Wang, Yanpeng Mao, Chunyuan Ma. Microwave drying performance of single-particle coal slime and energy consumption analyses. Fuel Processing Technology, 2016, vol. 143, pp. 69-78.

6. Faisal Mushtaq, Ramli Mat, Farid Nasir Ani. Fuel production from microwave assisted pyrolysis of coal with carbon surfaces. Energy Conversion and Management, 2016, vol. 110, pp. $142-153$.

7. Zhanlong Song, Liansheng Yao, Chuanming Jing, Xiqiang Zhao, Wenlong Wang, Chunyuan Ma. Drying behavior of lignite under microwave heating. Drying Technology, 2016, vol. 35, pp. $433-443$.

8. Radha Raman Mishra, Apurbba Kumar Sharma. Microwave-material interaction phenomena: Heating mechanisms, challenges and opportunities in material processing. Composites Part A: Applied Science and Manufacturing, 2016, vol. 81, pp. 78-97.

9. Huan-Peng Liu, Tai-Ping Chen, Yang Li, Zhen-Yu Song, ShaoWei Wang, Shao-Hua Wu. Temperature rise characteristics of Zhun Dong coal during microwave pyrolysis. Fuel Processing Technology, 2016, vol. 148, pp. 317-323.

10. Khaidurova A.A., Fedchishin V.V., Konovalov N.P. Mikrovolnovaya sushka burykh ugley i povyshenie ikh tekhnologicheskikh kharakteristik [Microwave drying of brown coals and increasing their technological characteristics]. Izvestiya VUZov. Problemy energetiki [Izvestiya Universities. Problems of energy]. Kazan, KGEU Publ., 2010. pp. 31-35.

11. Drozd J.M., Druga M.C., Lawson S.L., Lang F.Ch., Bullis H.L. Methods and systems for processing solid fuel. US20090272028A1 United States. Patent.

12. Yu Feng, Tianqi Hu, Mengmeng Wu, Ju Shangguan, Huilin Fan, Jie Mi. Effect of microwave irradiation on the preparation of iron oxide/arenaceous clay sorbent for hot coal gas desulfurization. Fuel Processing Technology, 2016, vol. 148, pp. 35-42.

13. He Li, Baiquan Lin, Wei Yang, Chunshan Zheng, Yidu Hong, Yabin Gao, Tong Liu, Shiliang Wu. Experimental study on the petrophysical variation of different rank coals with microwave treatment. International Journal of Coal Geology, 2016, vol. 154-155, pp. 82-91.

14. Thue P.S., Dos Reis G.S., Lima E.C., Sieliechi J.M., Dotto G.L., Wamba A.G.N., Dias S.L.P., Pavan F.A. Activated carbon obtained from sapelli wood sawdust by microwave heating for 0-cresol adsorption. Research on Chemical Intermediates, February 2017, vol. 43, Iss. 2, pp. 1063-1087.

15. Hong Yi-du, Lin Bai-quan, Zhu Chuan-jie, Li He. Effect of microwave irradiation on petrophysical characterization of coals. Applied Thermal Engineering, 2016, vol. 102, pp. 1109-1125.

16. Jing Sun, Wenlong Wang, Qinyan Yue. Review on MicrowaveMatter Interaction Fundamentals and Efficient Microwave-Associated Heating Strategies. Materials, 2016, pp. 231. DOI: 10.3390/ma904023.

17. Reddy B.R., Vinu R. Microwave assisted pyrolysis of Indian and Indonesian coals and product characterization. Fuel Processing Technology, 2016, vol. 154, pp. 96-103.

18. Zhiwei Peng, Xiaolong Lin, Xuejiao Wu, Jiann-Yang Hwang, Byoung-Gon Kim, Yuanbo Zhang, Guanghui Li, Tao Jiang. Microwave absorption characteristics of anthracite during pyrolysis. Fuel Processing Technology, 2016, vol. 150, pp. 58-63.

19. Lykov A.V. Teoriya teploprovodnosti [Theory of heat conductivity]. Moscow, Vysshaya shkola Publ., 1967. 600 p.

20. Lykov A.V. Teoriya sushki [The theory of drying]. Moscow, Energiya Publ., 1968. $471 \mathrm{p}$.

Received: 4 October 2019.

\section{Information about the authors}

Vladimir V. Salomatov, Dr. Sc., professor, Novosibirsk State University; senior researcher, Institute of Thermophysics. S.S. Kutateladze SB RAS

Vadim A. Karelin, postgraduate, Novosibirsk State University; research engineer, Institute of Thermophysics. S.S. Kutateladze SB RAS

Vasiliy V. Salomatov, Cand. Sc., leading programmer Institute of Thermophysics. S.S. Kutateladze SB RAS 